\title{
Influencia de la finura de molido del carbonato de calcio en las propiedades físico mecánicas y de durabilidad de los ladrillos de cerámica roja
}

\section{Influcence of grinding fineness of calcium carbonate on physic- chemical properties and durability on red ceramic bricks}

\author{
Yosvany Díaz*1, Dania Betancourt*, Fernando Martirena* \\ * Universidad Central de las Villas. CUBA

\begin{abstract}
Fecha de recepción: 03/ 03/ 2011 Fecha de aceptación: 09/07/2011 Resumen PAG. $269-283$

El trabajo hace un estudio de la influencia de la finura de molido del carbonato de calcio en las propiedades de Resistencia a la compresión, densidad, absorción y durabilidad de los ladrillos de cerámica roja, a través de la realización de ensayos físico- mecánicos y de envejecimiento acelerado, cuando este se adiciona por debajo del $10 \%$ en relación con el peso de la arcilla. Se demuestra que cuando dicho aditivo se muele hasta finuras entre las $7 \not 2 m$ y $150 \mu \mathrm{m}$, no se afectan las propiedades mencionadas anteriormente, sin embargo no ocurre así cuando es molido hasta un tamaño de partícula de $297 \mu \mathrm{m}$. El estudio realizado, demuestra que con esta superficie específica, la adición de calcita afecta tanto las propiedades físico-mecánicas como de durabilidad de los ladrillos de cerámica roja.
\end{abstract}

Palabras Clave: Ladrillos cocidos, agentes fundentes, durabilidad, propiedades mecánicas, carbonato de calcio

Abstract

The paper exposes the results of a study, at macro structural level, on the influence of the calcite grinding process fineness on the red ceramic bricks following properties: Compressive strength, Density, Absorption and Durability, though the performance of physical - mechanical and accelerated aging tests, when this is added in an amount inferior to the $10 \%$ in relation with the clay weight. It is proved that when this admixture is ground until fineness between 72 $\mu \mathrm{m}$ and $150 \mu \mathrm{m}$, the above mentioned properties are not affected, however it doesn't occur this way when it is ground until a particle size of $29 \bar{m}$. The carried out study, demonstrates that with this specific surface, the calcite addition affects the red ceramic bricks physical-mechanical properties as well as their durability

Keywords: Ceramic bricks, fluxing agents, durability, mechanical properties, calcium carbonate

\section{Introducción}

\footnotetext{
1 Autor de correspondencia / Corresponding author:

E-mail: Yosvanyd@uclv.edu.cu
}

\section{Introduction}

The use of calcium carbonate as additive for the elaboration of red bricks, has been studied by several authors, (Cultrone et al., 2000; Jordan et al., 2001; Xavier, 2004), in those cases, such addition is generally reported at high rates for burning temperatures, ranging from 900 to $1000{ }^{\circ} \mathrm{C}$. Under such conditions, the changes introduced by the carbonates presence on bricks mechanical properties shall be taken into consideration, which basically lead to a reduction of strength and durability. 
The use of finely ground calcium carbonate in very small additions (ranging from 2 to $5 \%$ ) (Betancourt et al., 2007) has also been reported with the purpose of improving energetic efficiency on the firing process, without affecting red brick properties. It was demonstrated that the addition of calcium carbonate into the clay admixture in amounts ranging from 2 to $5 \%$ improves bricks compressive strength at temperatures close to $900^{\circ} \mathrm{C}$ and, it also improves sintering periods from 1 to 3 hours. Such effect is explained by the modification of reactions occurring in clays during a thermal treatment, due to the presence of calcite mineral, which enables the sintering process at lower temperatures in studied clays, which mineralogical composition is mainly montmorillonite mineral. (Betancourt et al., 2007).

From the research and kinetic mathematical modeling on the reaction (García, 2005), it was learnt that the grinding fineness of calcium carbonate influences decarbonization reaction rate taking place when it is placed at temperatures close to $900{ }^{\circ} \mathrm{C}$. Besides influencing calcite decarbonization reaction rate, it has also been studied that the specific surface of calcium carbonate added into a clay admixture also influences the properties of the final ceramic product, such as: compressive strength, water absorption, material porosity and density among others, since at lower specific surface there will be a great amount of non-reactive $\mathrm{CaO}$ remaining on the product mass - which chemically combined with silica and alumina contained in clays - will get in contact with the atmosphere water vapor thus turning into $\mathrm{CaOH}$. This is an expansive reaction that produces fissures and cracks on ceramic products by affecting their physicmechanical properties and durability. (Cultrone et al., 2000; Cultrone, 2005).

The current research considers the principle of using small dosages of calcium carbonate (less than $10 \%$ of clay weight) as fluxing agents on the elaboration red bricks, so as to study the grinding fineness influence on physical-chemical properties and durability on red ceramic bricks, fired at temperatures ranging from $800^{\circ} \mathrm{C}$ and $1000^{\circ} \mathrm{C}$, with a burning lifetime of 3 hours.

For this research work, the aforementioned fluxing agent was selected among others, because for the Cuban case its use becomes quite convenient due to economic reasons since it is very economical compared to other fluxing agents; it is available in construction field; 
its excellent quality regarding purity and chemical composition are the same in the market industry as well as for the ones obtained as residues from limestone and marble quarries.

\section{Discusion and execution}

The current research job was executed in two stages: the first consisted in the laboratory test of the grinding fineness of calcium carbonate added into a regular clay admixture used to elaborate bricks, on physical-mechanical properties and durability of the cylindrical specimens elaborated at the laboratory. The second stage consisted in the application of such test results in the elaboration of bricks, at full scale, at a factory producer of tiles and bricks.

\subsection{Experiment Layout}

2.1.1 Experimental research at laboratory scale In this research job, ordinary clay was used with quite heterogeneous composition coming from "La Mosa" quarry, located in the Manicaragua town, province of Villa Clara. Clay $x$-ray tests indicated that minerals contained in it are montmorillonite and kaolinite (x-ray test results from researched clay are shown in Figure 1). High purity calcium carbonate comes from Palenque quarry in Remedios town, province of Villa Clara. Table 1 shows chemical composition for both materials.

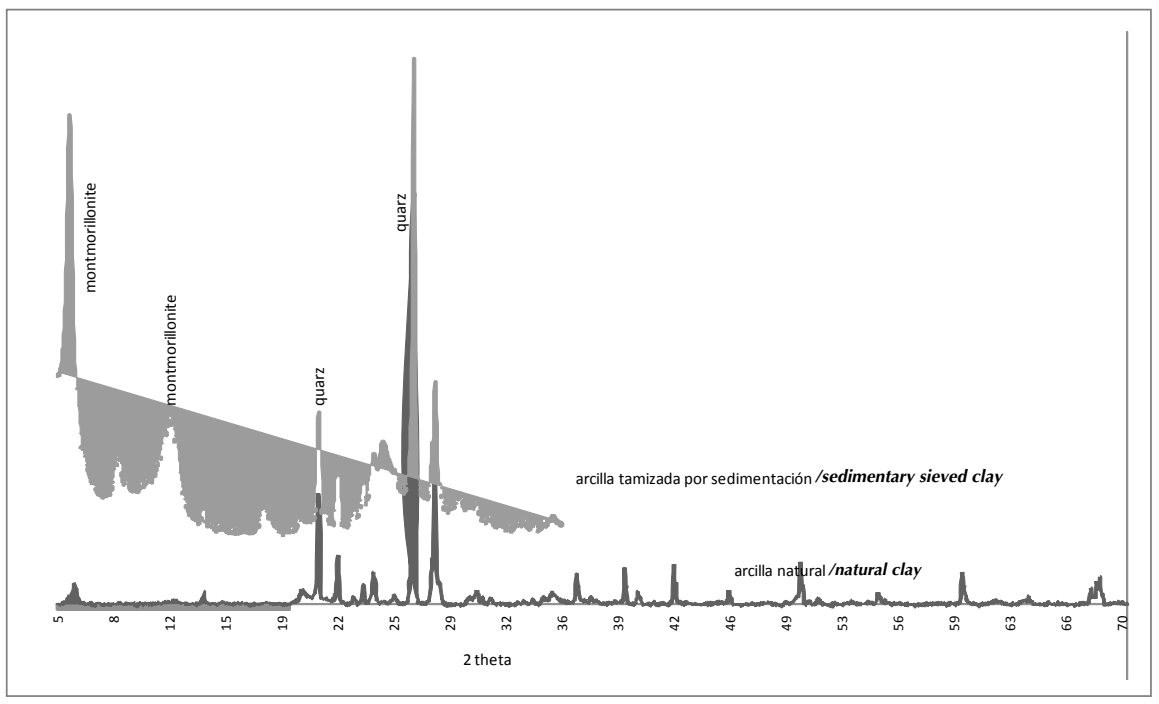

Figura 1. Resultados de la comparación de fases en arcilla natural y sedimentada Figure 1. Results of comparison between natural clay and sedimentary clay phases 
Tabla 1. Composición química de las materias primas

Table 1. Chemical composition of raw materials

\begin{tabular}{|c|c|c||}
\hline Determinación \%/Apportionment $\%$ & Arcilla/Clay & Carbonato de calcio/Calcium carbonate \\
\hline $\mathrm{SiO}_{2}$ & 49.56 & 0.2 \\
\hline $\mathrm{Al}_{2} \mathrm{O}_{3}$ & 10.41 & 0.5 \\
\hline${\mathrm{Fe} 2 \mathrm{O}_{3}}$ & 10.73 & 0.13 \\
\hline $\mathrm{TiO}_{2}$ & 0.88 & 0.02 \\
\hline $\mathrm{CaO}$ & 3.82 & 54.78 \\
\hline $\mathrm{MgO}$ & 12.32 & 0.27 \\
\hline $\mathrm{Na}_{2} \mathrm{O}$ & 1.39 & 0.1 \\
\hline $\mathrm{K}_{2} \mathrm{O}$ & 0.22 & 0.1 \\
\hline $\mathrm{P}_{2} \mathrm{O}_{5}$ & 0.07 & 0.09 \\
\hline $\mathrm{MnO}$ & 0.16 & 0.01 \\
\hline $\mathrm{SO}_{3}$ & $<0.10$ & 0.1 \\
\hline $\mathrm{PPI}$ & 9.04 & 43 \\
\hline $\mathrm{CaCO}_{3}(\%)$ & 0 & 97.63 \\
\hline
\end{tabular}

Dry clay was mixed with finely ground calcium carbonate into three different finenesses: 297um, 150 $\mu \mathrm{m}$ and $72 \mu \mathrm{m}$, the admixture was prepared in two proportions: $5 \%$ and $8 \%$ of total clay mass. The mass was moistened from 8 to $10 \%$, well homogenized and molded in cylindrical test specimens with $3.1 \mathrm{~cm}$ diameter, which were placed at molding pressure of $7 \mathrm{MPa}$. Cylindrical test specimens were dried at environmental temperature during 3-5 days; subsequently they were fired by means of an electric furnace. Table 2 shows the whole information on elaborated specimens.

Firing process was divided into two phases: a) removal of combined water up to $400^{\circ} \mathrm{C}$ and b) hard burnt temperature. The specimens were kept during 4 hours in the phase a) and 3 hours in phase b). Three firing temperatures were: $800^{\circ} \mathrm{C}, 900{ }^{\circ} \mathrm{C}$ and $1000{ }^{\circ} \mathrm{C}$ in phase b). Figure 2 shows different firing regimens. 
Influencia de la finura del molido del carbonato de calcio/Influence of grinding fineness of calcium carbonate

Tabla 2. Especímenes fabricados

Table 2. Elaborated specimens

\begin{tabular}{|c|c|c|c|}
\hline Muestras ID/ID Samples & $\operatorname{Tem}^{\circ} \mathrm{C}$ & $\% \mathrm{CaCO}_{3}$ & Finura/Fineness \\
\hline M1 & 800 & 5 & $150 \mu m$ \\
\hline M2 & 800 & 8 & $150 \mu m$ \\
\hline M3 & 800 & 5 & $72 \mu m$ \\
\hline M4 & 800 & 8 & $72 \mu m$ \\
\hline M5 & 800 & 5 & $297 \mu m$ \\
\hline M6 & 800 & 8 & $297 \mu m$ \\
\hline M7 & 900 & 5 & $150 \mu m$ \\
\hline $\mathbf{M 8}$ & 900 & 8 & $150 \mu m$ \\
\hline M9 & 900 & 5 & $72 \mu m$ \\
\hline M10 & 900 & 8 & $72 \mu m$ \\
\hline M11 & 900 & 5 & $297 \mu m$ \\
\hline M12 & 900 & 8 & $297 \mu m$ \\
\hline M13 & 1000 & 5 & $150 \mu m$ \\
\hline M14 & 1000 & 8 & $150 \mu m$ \\
\hline M15 & 1000 & 5 & $72 \mu m$ \\
\hline M16 & 1000 & 8 & $72 \mu \mathrm{m}$ \\
\hline M17 & 1000 & 5 & $297 \mu m$ \\
\hline M18 & 1000 & 8 & $297 \mu \mathrm{m}$ \\
\hline
\end{tabular}

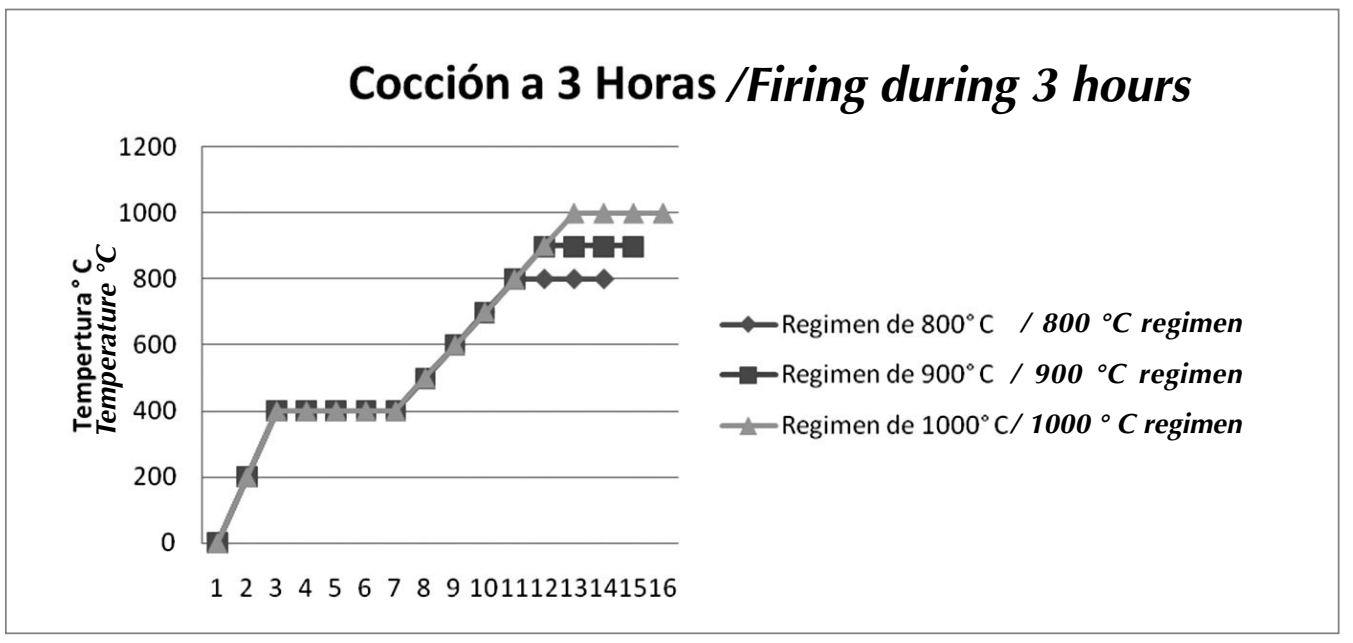

Figura 2. Regímenes de temperatura, con tiempo de quema de 3 horas Figure 2. Temperature regimens for 3 hours of firing time 
Specimens elaborated were subjected to the following tests:

1. Compressive strength

2. Density

3. Water absorption

4. Dampening and drying cycles

5. Salts crystallization

The results obtained from analyzed samples, for the case of physical-mechanical tests, were compared to the ones established by Cuban regulation: NC 3592005, which certifies the quality for standard red ceramic bricks. Regarding to durability study, which consisted in the execution of salts crystallization tests and dampening and drying samples tests, the procedures as well as the results comparison were executed in accordance with Spanish regulation UNE 7-136-58.

2.1.2 Experimental research at full production scale By using the best results obtained at the laboratory, the experiment concluded with the elaboration of bricks at full scale in a factory producer of red ceramic bricks, which installed capacity is 100000 units per month. Bricks with a $5 \%$ addition of finely ground calcium carbonate, which fineness was $150 \mu \mathrm{m}$, were burnt inside a discontinuous furnace with a 6800-bricks firing capacity. During burning process, firing time was measured as well as furnace's fuel consumption and samples were taken (bricks) in order to check the quality on final product by means of the execution of compressive strengths, density and absorption tests. The same procedure was carried out during firing process on bricks with no-addition of calcium carbonate in the same furnace, taking this burning as a control pattern in order to compare results from both burning processes.

\section{Results discussion}

3.1 Discussion of results at laboratory scale 3.1.1 Physical-chemical properties

Figure 3 shows the relation between average compressive strength on tested cylinders with firing temperature and added finely ground calcium carbonate, which in this case was $5 \%$. A series of 9 specimens were tested, which provided a standard deviation oscillating from 0. 25 - $0.55 \mathrm{MPa}$, Figure 3. 


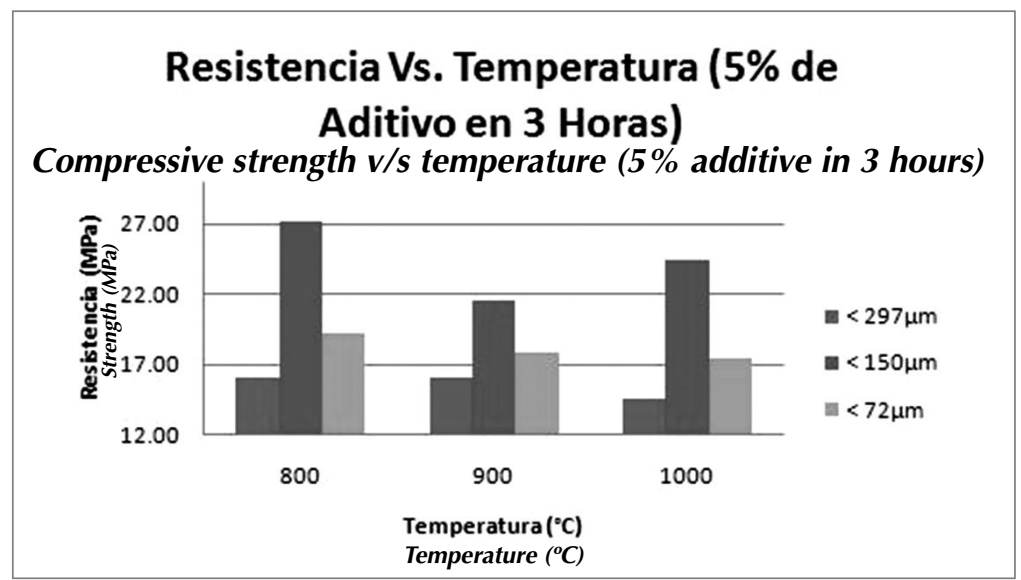

Figura 3. Gráfico de resistencia vs temperatura para las tres finuras de molido del carbonato de calcio. (5\% de adición) Figure 3. Graph Compressive Strength v/s temperature for the different finenesses of ground calcium carbonate (5\% addition)

As observed in Figure 3, at three firing temperatures the highest compressive strength values are obtained for calcium carbonate particle size of $150 \mathrm{um}$ and $72 \mu \mathrm{m} ;$ and there is a significant compressive strength drop for specimens tested with 297um grinding fineness.

Something similar occurs in the case of Density. As long as grinding fineness increases in the fluxing agent, there is a significant increase of density in the specimens and this relevant difference is demonstrated between 297 $\mu \mathrm{m}$ and $150 \mu \mathrm{m}$ finenesses (Figure 4).

Figure 5 shows the considerable increase of water absorption taking place when grinding fineness decreases. It is noticed that specimens elaborated with grinding fineness of $297 \mu \mathrm{m}$ at firing temperatures of $800^{\circ} \mathrm{C}$ and $900^{\circ} \mathrm{C}$, they achieve the maximum water absorption value allowed by Cuban regulation NC 3592005 for standard red ceramic bricks (18\%). By increasing temperature at $1000^{\circ} \mathrm{C}$, water absorption values considerably decrease for the three fluxing agent fineness sizes, because at this temperature and, due to the calcite addition, the material vitrification takes place thus diminishing pores amount (Betancourt et al., 2007). Figures 4 and 5. 


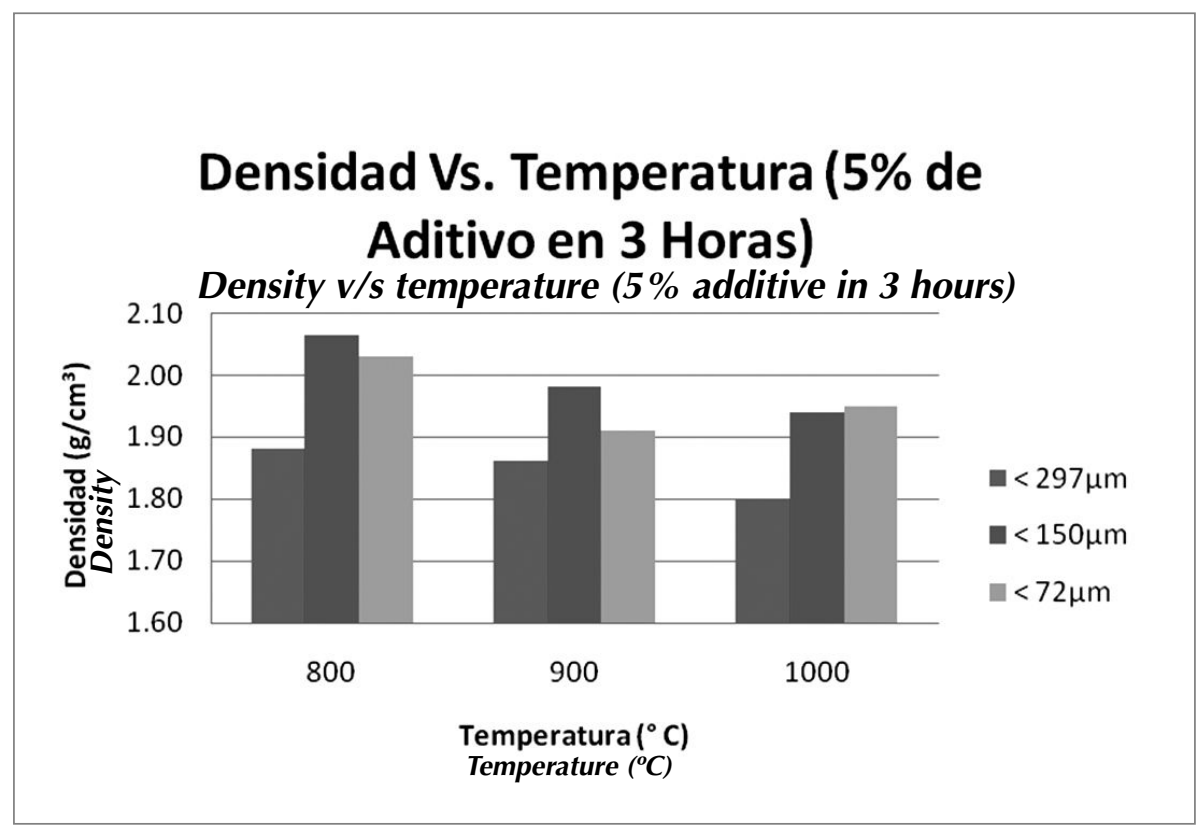

Figura 4. Gráfico de Densidad vs Temperatura para las tres finuras de molido del carbonato de calcio. (5\% de adición) Figure 4. Graph Density v/s temperature for the three different calcium carbonate grinding finenesses (5\% addition)

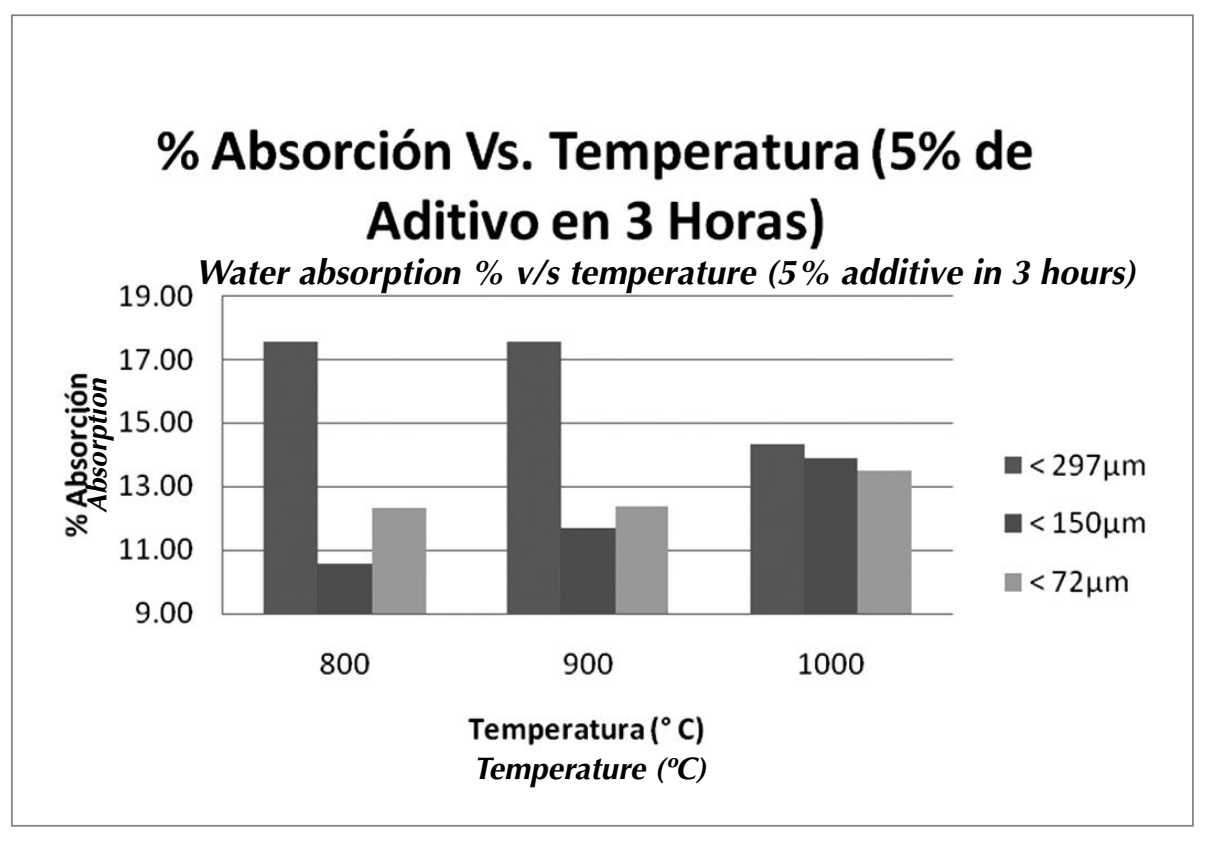

Figura 5. Gráfico de absorción vs temperatura para las tres finuras de molido del carbonato de calcio. (5\% de adición) Figure 5. Graph water absorption v/s temperature for the three ground calcium carbonate finenesses (5\% addition) 
When increasing calcite addition percentage, from $5 \%$ up to $8 \%$, compressive strength and density decrease for all tested samples. Such drop becomes quite significant for samples elaborated with additive grinding fineness of $297 \mu \mathrm{m}$, as shown in Figures 6 and 7.

In the same way as $5 \%$ addition, for $8 \%$ series of 9 specimens were tested, and the obtained results delivered a standard deviation from 0.33 to 0.50 regarding compressive strength and from 0.33 to 0.55 for density test.

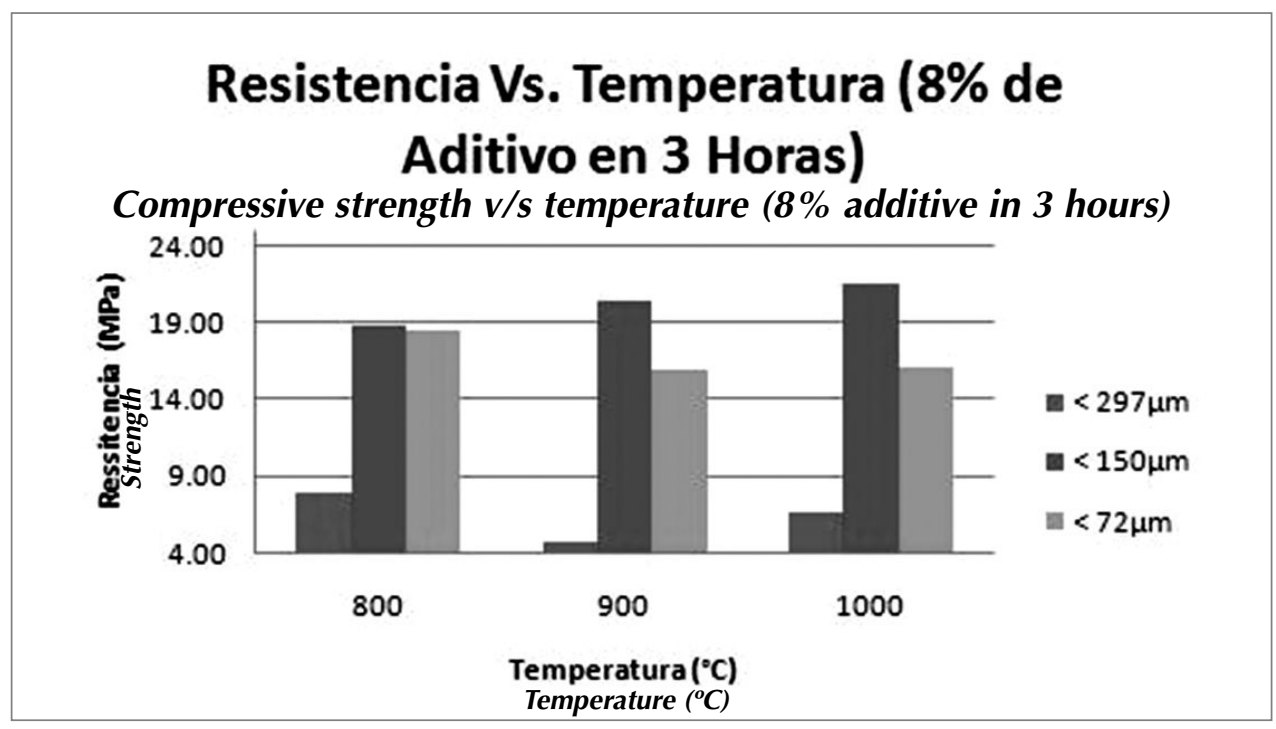

Figura 6. Gráfico de resistencia vs temperatura para las tres finuras de molido del carbonato de calcio. (8\% de adición) Figure 6. Graph Compressive strength $v / s$ Temperature for three different calcium carbonate grinding finenesses (8\% addition)

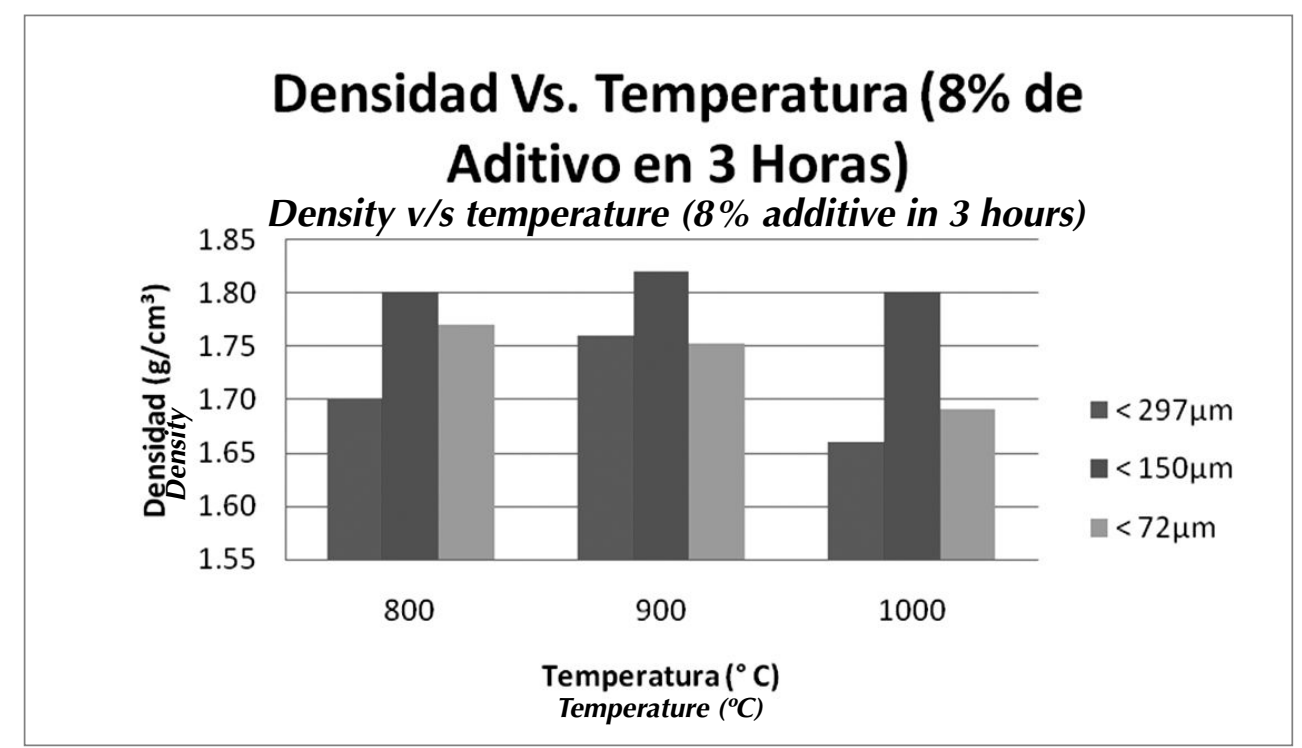

Figura 7. Gráfico de densidad vs temperatura para las tres finuras de molido del carbonato de calcio. (8\% de adición) Figure 7. Graph Density v/s Temperature for the three different calcium carbonate grinding finenesses ( $8 \%$ addition) 
In the case of $8 \%$ calcite addition, water absorption in cylinders elaborated with a grinding fineness of $297 \mu \mathrm{m}$ and burnt at $900^{\circ} \mathrm{C}$ and $1000^{\circ} \mathrm{C}$, it exceeds the maximum value allowed by Cuban regulation NC 359-2005 (18\%).

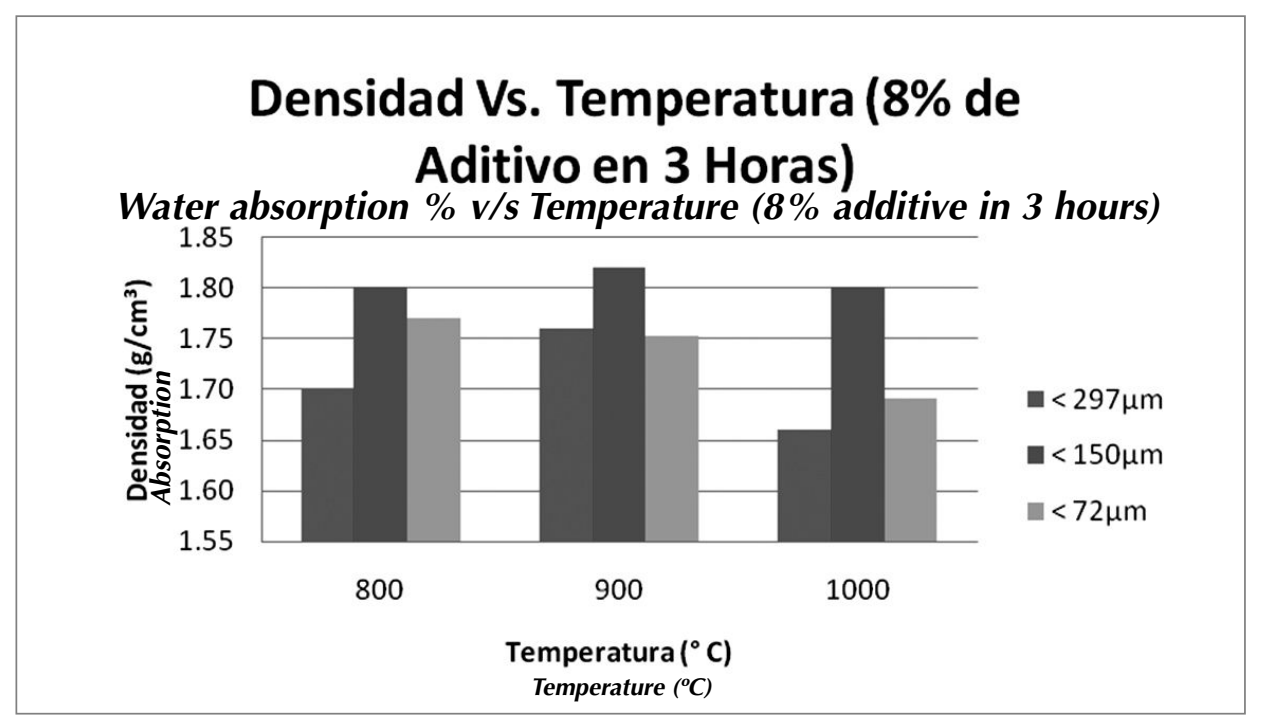

Figura 8. Gráfico de Absorción vs Temperatura para las tres finuras de molido del carbonato de calcio. (8\% de adición) Figure 8. Graph Water Absorption v/s Temperature for the three different calcium carbonate grinding finenesses ( $8 \%$ addition)

\subsubsection{Results discussion on durability test}

Results obtained from accelerated aging tests are in accordance with the ones achieved from mechanical properties test. In the case of specimens elaborated with additive fineness of $297 \mu \mathrm{m}$, all the specimens, at three studied firing temperatures in both tests, were destroyed by ending the first cycle, because of the great amount of calcrete contained in the samples.

A quite different behavior was presented by specimens elaborated with calcium carbonate finenesses of $150 \mu \mathrm{m}$ and $72 \mu \mathrm{m}$. All specimens resisted the 15 immersion cycles in decahydrate sodium sulfate at $14 \%$ for the case of salts crystallization, and also the $\mathbf{3 0}$ dampening and drying cycles pre-established for this trial.

For durability research, besides testing specimens elaborated with $5 \%$ and $8 \%$ addition of calcium carbonate at above mentioned temperatures, it included the elaboration of two series of 9 specimens with $0 \%$ of calcite addition, which are identified in Table 3 as MP-1 and MP-2. For the first, 
the specimens were burnt at $800^{\circ} \mathrm{C}$ and for the second case at $900^{\circ} \mathrm{C}$, so as to compare the behavior of series elaborated with addition to specimens elaborated without calcite addition.

Tabla 3. Resultados de los ensayos de Envejecimiento acelerado Table 3. Results from accelerated aging tests

\begin{tabular}{|c|c|c|c|c|}
\hline $\begin{array}{l}\text { Muestras } \\
\text { Samples }\end{array}$ & $\begin{array}{l}\text { Pérdida de peso en gramos. } \\
\text { Weight loss in grams } \\
\text { Cristalización de sales. } \\
\text { Salt Crystallization }\end{array}$ & $\begin{array}{l}\text { Pérdida de peso en gramos. } \\
\text { Weight loss in grams } \\
\text { Humedecimiento y secado. } \\
\text { Dampening and drying }\end{array}$ & $\begin{array}{l}\text { Temperatura }^{\circ} \mathrm{C} \\
\text { Temperature }^{\circ} \mathrm{C}\end{array}$ & $\begin{array}{l}\text { Finura de molido del } \mathrm{CaCO}_{3} \\
\mathrm{CaCO}_{3} \text { Grinding fineness }\end{array}$ \\
\hline MP-1 & -2.50 & -0.5 & 800 & \\
\hline MP-2 & -1.50 & $\boldsymbol{O}$ & 900 & \\
\hline$M-1$ & -2.00 & $\boldsymbol{O}$ & 800 & Finura/Fineness $150 \mu \mathrm{m}$ \\
\hline$M-2$ & -3.00 & -1.00 & 800 & Finura/Fineness $150 \mu \mathrm{m}$ \\
\hline$M-3$ & -2.00 & $\boldsymbol{0}$ & 800 & Finura/Fineness $72 \mu \mathrm{m}$ \\
\hline$M-4$ & -2.50 & -0.2 & 800 & Finura/Fineness $72 \mu \mathrm{m}$ \\
\hline$M-5$ & Desintegrada/Desintegrated & Desintegrada/Desintegrated & 800 & Finura/Fineness $297 \mu \mathrm{m}$ \\
\hline M-6 & Desintegrada/Desintegrated & Desintegrada/Desintegrated & 800 & Finura/Fineness $297 \mu \mathrm{m}$ \\
\hline$M-7$ & -2.00 & -0.5 & 900 & Finura/Fineness $150 \mu \mathrm{m}$ \\
\hline$M-8$ & -3.00 & -1.5 & 900 & Finura/Fineness $150 \mu \mathrm{m}$ \\
\hline$M-9$ & -3.00 & -0.1 & 900 & Finura/Fineness $72 \mu \mathrm{m}$ \\
\hline$M-10$ & -3.00 & -0.2 & 900 & Finura/Fineness $72 \mu \mathrm{m}$ \\
\hline$M-11$ & Desintegrada/Desintegrated & Desintegrada/Desintegrated & 900 & Finura/Fineness $297 \mu \mathrm{m}$ \\
\hline M-12 & Desintegrada/Desintegrated & Desintegrada/Desintegrated & 900 & Finura/Fineness $297 \mu \mathrm{m}$ \\
\hline
\end{tabular}

As clearly indicated in above table, cylinders fabricated with grinding fineness of $150 \mu \mathrm{m}$ and $72 \mu \mathrm{m}$, had an excellent behavior in both tests, quite similar to the specimens elaborated under same production conditions without calcium carbonate addition, excepting samples M-2 and M-8, since their addition percentage increased from 5 to $8 \%$, thus their performance is slightly deficient compared to the other samples including patterns or control series.

3.2 Results discussion from red brick firing process at full scale (Discontinuous furnace)

After completing the burning process at full furnace capacity ( 6800 bricks with $5 \%$ calcium carbonate addition), at full scale production, it was demonstrated that the minimum grinding fineness to be added into a red brick admixture, at small dosages, is $150 \mu \mathrm{m}$; then it is not necessary to grind additive up to a higher fineness $o$ act effectively as fluxing agent neither to positively influence the physical-mechanical properties of this material, 
because it would lead to a higher energy consumption during grinding process which is useless for massive production at small, medium and big size industries.

As result from temperature measurement, duration of firing stage and fuel consumption by discontinuous furnace, temperature curves v/s time (Figure 9) were obtained for burning with calcium carbonate addition and for burning control pattern, as shown in Figure 10.

Due to the addition of calcium carbonate, the furnace fuel consumption was reduced in $21.5 \%$ regarding burning pattern. Average temperature experienced a decrease of $80^{\circ} \mathrm{C}$ and burning lifetime decreased in 3.5 hours, thus demonstrating its effectiveness as clay fluxing agent when used in small proportions.

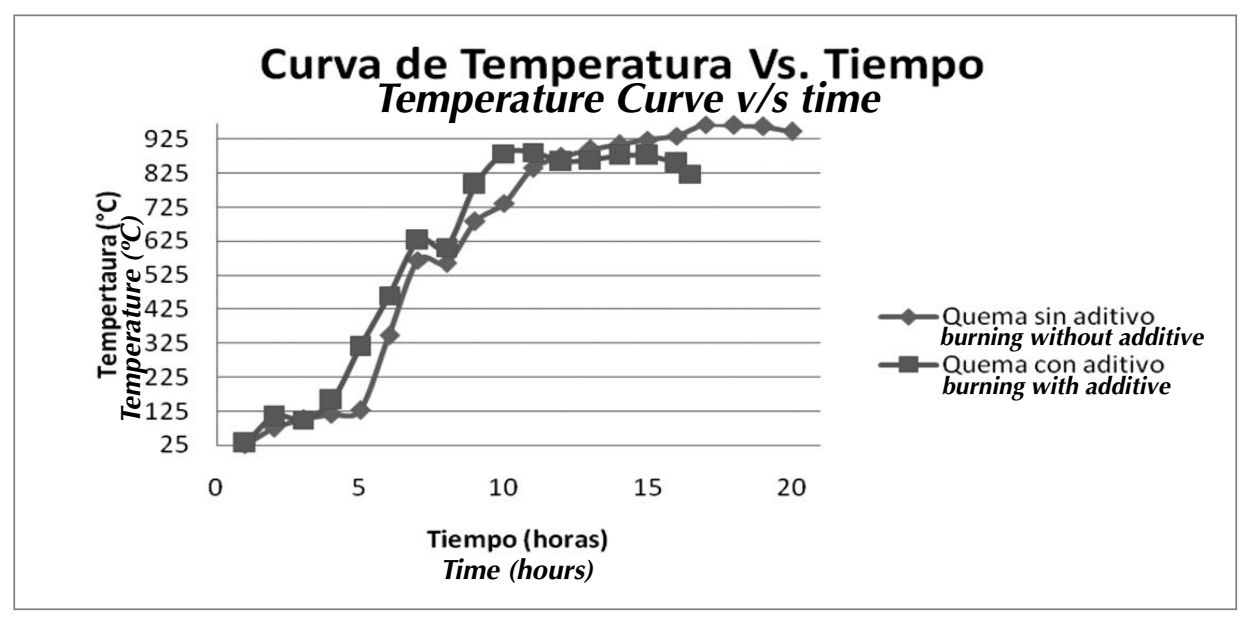

Figura 9. Curvas de la etapa de cocción de ambas quemas

Figure 9. curves from firing stage for both burning processes

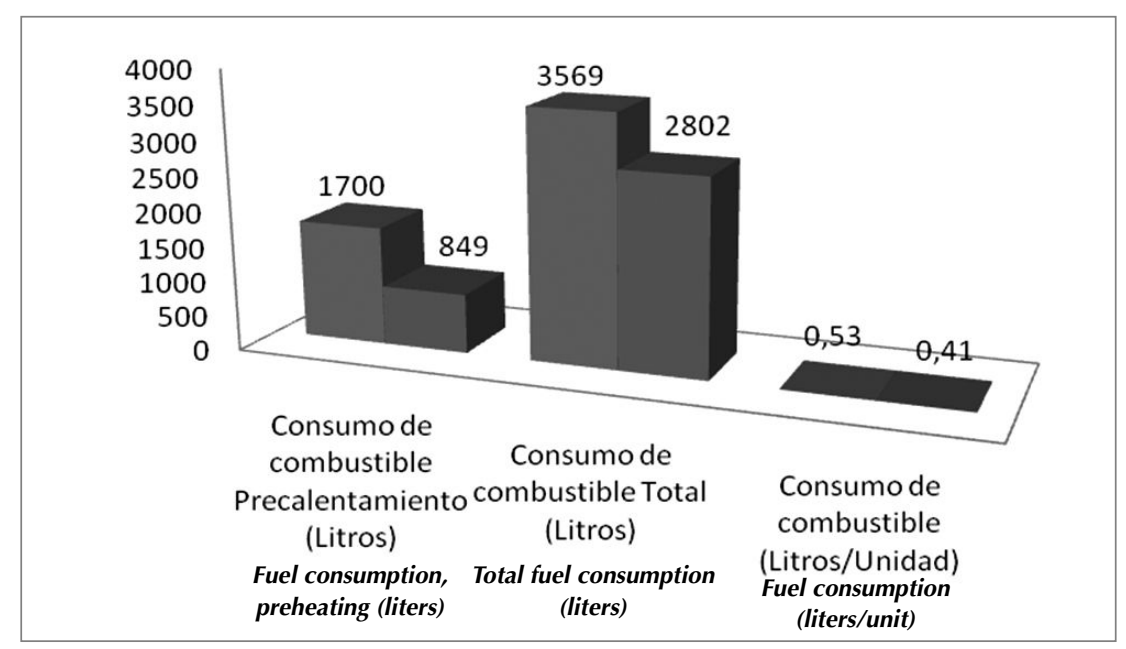

Figura 10. Consumo de combustible por etapas

Figure 10. Fuel consumption per stages 
The results of compressive strength, density and water absorption tests developed on bricks removed from the furnace are shown below.

Tabla 4. Resultados del ensayo de Resistencia a la compresión para ladrillos con y sin adición de $\mathrm{CaCO}_{3}$ Table 4. Compressive strength test results obtained from bricks with and without $\mathrm{CaCO} 3$ addition

\begin{tabular}{|c|c|c||}
\hline Muestra/Sample & Resistencia/Strength (MPa) $0 \% \mathrm{CaCO}_{3}$ & Resistencia (MPa) 5\% CaCO \\
\hline 1 & 10.10 & 11.85 \\
\hline 2 & 9.80 & 11.57 \\
\hline 3 & 9.80 & 11.19 \\
\hline 4 & 9.10 & 11.28 \\
\hline 5 & 9.80 & 10.96 \\
\hline 6 & 10.60 & 11.83 \\
\hline 7 & 9.90 & 11.20 \\
\hline 8 & 9.60 & 11.50 \\
\hline 9 & 10.20 & 11.37 \\
\hline 10 & 9.90 & 10.97 \\
\hline $\bar{R}$ & 9.88 & 11.37 \\
\hline Desviación estándar & 0.39 & 0.32 \\
\hline Coeficiente de variación & 0.04 & 0.03 \\
\hline
\end{tabular}

Tabla 5. Resultados del ensayo de Absorción para ladrillos con y sin adición de $\mathrm{CaCO}_{3}$ Table 5. Results from water absorption test on bricks with and without $\mathrm{CaCO} 3$ addition

\begin{tabular}{||c|c|c||}
\hline Muestra/Sample & Absorción/Absorption (\%) $\%$ CaCO, & Absorción/Absorption (\%)5\% CaCO \\
\hline$M 1$ & 9.63 & 11.33 \\
\hline$M 2$ & 12.10 & 10.17 \\
\hline$M 3$ & 11.69 & 10.95 \\
\hline$M 4$ & 10.79 & 10.99 \\
\hline$M 5$ & 11.85 & 10.43 \\
\hline$M 6$ & 11.75 & 10.89 \\
\hline$M 7$ & 11.11 & 11.17 \\
\hline$M 8$ & 9.66 & 11.84 \\
\hline$M 9$ & 12.15 & 11.05 \\
\hline M10 & 12.17 & 11.92 \\
\hline $\bar{A}$ & 11.29 & 11.07 \\
\hline $\begin{array}{c}\text { Desviación estándar } \\
\text { Coeficiente de variación }\end{array}$ & 0.97 & 0.55 \\
\hline Defficient of variation & & 0.05 \\
\hline
\end{tabular}


Tabla 6. Resultados del ensayo de Densidad para ladrillos con y sin adición de $\mathrm{CaCO}_{3}$

Table 6. Results from Density test on bricks with and without $\mathrm{CaCO} 3$ addition

\begin{tabular}{|c|c|c|}
\hline Muestra/Sample & Densidad/Density & Densidad/ Density \\
& $\left(\mathrm{g} / \mathrm{cm}^{3}\right)$ O $\mathrm{CaCO}_{3}$ & 1.9 \\
\hline 1 & 1.75 & 1.91 \\
\hline 2 & 1.91 & 1.95 \\
\hline 3 & 1.86 & 1.93 \\
\hline 4 & 1.94 & 1.98 \\
\hline 5 & 1.91 & 1.98 \\
\hline 6 & 1.90 & 1.97 \\
\hline 7 & 1.88 & 1.95 \\
\hline 8 & 1.96 & 1.96 \\
\hline 9 & 1.95 & 1.97 \\
\hline 10 & 1.93 & 1.95 \\
\hline $\bar{D}$ & 1.90 & 0.03 \\
\hline Coeficiente de variación/Coefficient of variation & 0.06 & 0.01 \\
\hline \hline
\end{tabular}

\section{Conclussions}

1. It was demonstrated that calcium carbonate addition in very small dosages and grinded up to $297 \mu \mathrm{m}$ fineness, influences negatively the physical-chemical properties of red ceramic bricks. Only from 150 $\mu$ m, the addition of calcite becomes convenient for material quality in small quantities (less than $10 \%$ of clay weight).

2. Significant differences were not found in test results for compressive strength, density and absorption delivered by the series of specimens elaborated with additive grinding finenesses of $150 \mu \mathrm{m}$ and $72 \mu \mathrm{m}$, for $2 \%$ addition used in this experiment.

3. Results for accelerated aging tests agree with the ones obtained from mechanical properties test, both studies carried out in the experimental phase proved that calcium carbonate grinding fineness added in small dosages, influenced negatively red ceramic bricks durability when it is ground up to $297 \mu \mathrm{m}$ fineness. This particle size lead to the disintegration of all the samples, while cylinders elaborated with a grinding fineness of $150 \mu \mathrm{m}$ and $72 \mu \mathrm{m}$ experienced an excellent behavior in both tests. 
4. Quality test results on bricks elaborated at full scale and burnt by a discontinuous furnace and also from firing stage modeling, do confirm the results obtained at laboratory scale and demonstrate that calcium carbonate addition may be an increasing source of energetic efficiency for the production of this material.

\section{Referencias / References}

Betancourt D., Martirena J.F., Day R.L. y Diaz Y. (2007), Influencia de la adición de carbonato de calcio en la eficiencia energética de la producción de ladrillos de cerámica roja. Revista "Ingeniería de Construcción". No 3. Volumen 22. Pags.187196 .Diciembre de 2007. Chile.

Cultrone G., de la Torre M.J., Sebastián E., Cazalla O. y Rodríguez C. (2000), Behaviour of bricks simples in aggresive environments. Water, Air and Soil Pollution 119: 191-207, 2000.

Cultrone G. et al. (2003), Durability of bricks used in the conservation of historic buildings-influence of composition and micro structure. Journal of Cultural Heritage 4 pág $91-99$

Cultrone G. (2004), Influence of mineralogy and firing temperature on the porosity of bricks. Journal of the European Ceramic Society 24 (2004) 547-564

Cultrone G. et al. (2005), Mineralogical and Physical Behavior of Solid Bricks with Additives. Construction and Building Materials 19 (2005) 39-48.

Day R.L y Huizer A. (1994), Fly-Ash Masonry Unit, Report published at the Department of Civil Engineering, University of Calgary, Canada, February 28, 1994.

Day R.L. et al. (1986), Engineering and Microstructural studies of Western-Canadian fly ash bricks. Department of Civil Engineering of the University of Calgary. Materials Research Society, Symposia Proceedings, volume 65, December 1986. 11p

Jordán M. M. et al. (2001), Aptitudes cerámicas de una arcilla tipo modificada por la adición de un residuo rico en carbonato calcico. Materiales de Construcción 51 No. 261, 2001, pp 5-19.

Karfa Traore, Tibo Simeon Kabre y Philippe Blanchart (2003), Gehlenite and anorthite crystallization from kaolinite and cal cite mix. Ceramics International 29 (2003) 377-383.

Karfa Traore y Philippe Blanchart (2003), Structural transformation of a kaolinite and calcite mixture to gehlenite and anorthite. Journal of Material Research, Vol. 18, February 2003

Mayoral M.C., Izquierdo M.T., Andres J.M. y Rubio B. (2001), Aluminosilicates transformations in combustion followed by DSC. Thermochimica Acta 373 (2001) 173-180.

Xavier E. (2004), Optimización de procesos cerámicos industriales. 1 ra Parte. Introducción al comportamiento de las pastas cerámicas. Publicado en internet en http:// www.cnpml.org/html/archivos/Ponencias/Ponencias-ID57.pdf. 